Рогов П. Д., к.т.н. ${ }^{1}$;

Ткаченко В. А., к.військ.н. ${ }^{1}$;

Голубцов С. M. ${ }^{2}$

${ }^{1}$-Центр воєнно-стратегічних досліджень Національного університету оборони України імені Івана Черняховського, Київ;

2 - Інститут державного військового управління Національного університету оборони України імені Івана Черняховського, Київ

\title{
Удосконалення морально-психологічного забезпечення як невід'ємна складова захисту військ (сил) та протидії негативному інформаційно-психологічному впливу
}

\begin{abstract}
Резюме. В статті розглянуто інформаційно-психологічний вплив, як специфічне явище сучасності та ефективний засіб досягнення цілей на тактичному, оперативному і стратегічному рівнях. Розглянуто систему протидії негативному інформаційному впливу на особовий та керівний склад 3С України в екстремальних і звичайних умовах діяльності.

Ключові слова: захист, інформаційно-психологічна протидія, інформаційно-психологічний вплив.
\end{abstract}

Постановка проблеми. Актуальність теми визначається: необхідністю комплексного та системного визначення дієвих механізмів управління інформаційною безпекою оборонної сфери України в умовах ведення проти неї інформаційної війни, особливо деструктивного маніпулятивного зовнішнього i внутрішнього інформаційнопсихологічного впливу 3 використанням інформаційної зброї (тобто інформаційного тероризму) на військовослужбовців Збройних Сил України та інших військових формувань держави; нагальною потребою глибокого дослідження інформаційного простору України та технологій виявлення сугестивного негативного інформаційно-психологічного впливу; політико-правовою невизначеністю системи інформаційно-психологічної безпеки України; необхідністю формування перспективних напрямів політики державного управління інформаційною безпекою та запровадження передового світового досвіду організації інформаційно-психологічної протидії.

Інформаційно-психологічний вплив (IПсB) - це такий вплив на індивідуальну та / або суспільну свідомість (підсвідомість) інформаційно-психологічними чи іншими способами, що викликає трансформацію психіки, зміну поглядів, думок, відносин, ціннісних орієнтацій, мотивів, стереотипів особистості з метою вплинути на її діяльність i поведінку. Кінцевою його метою $\epsilon$ досягнення певної реакції, поведінки (дії або бездіяльності) особи, яка відповідає цілям психологічного впливу [1-3, 6-10].
Людина, iї життя та здоров'я, честь i гідність, недоторканість та особиста безпека людини і громадянина визнаються в Україні найвищою соціальною цінністю. Держава зобов'язується охороняти та захищати інтереси свого населення, кожного іiї громадянина, як в Україні так і поза їі межами. Ці питання набувають особливого значення в період надзвичайного стану в країні, зокрема, в умовах загострення ситуацій соціального та воєнного характеру, ускладнення воєнно-політичної обстановки, гібридної війни тощо, оскільки за таких умов значно ускладнюється життедіяльність військовослужбовців та місцевого населення i стає неможливим ефективний розвиток суспільства й держави в цілому.

Аналіз останніх досліджень i публікацій. Різні аспекти здійснення протидії негативному інформаційно-психологічному впливу (IПсВ) на особовий склад військ (сил) під час виконання службово-бойових завдань військовослужбовцями силових структур розглядались у наукових працях та дослідженнях В. М. Богуша, Г. В. Грачова, I. В. Замаруєвої, О. Г. Караяні, В. Г. Криська, О. В. Литвиненка, А. Г. Лук'янця, О. А. Матеюка, І. К. Мельника, М. О. Попова, Г. Г. Почепцова, С. П. Расторгуєва, А. О. Рося, В. Б. Толубка, А. І. Черняка, О. К. Юдіна та інших науковців. Аналіз цих та інших праць свідчить, що:

існуюче нині розуміння протидії негативному IПсВ має неоднозначне тлумачення у різних наукових джерелах, що не сприяє визначенню його сутності та змісту, і як результат - зниження іiї ефективності; 
результати сучасних наукових досліджень не надають достатньої бази для здійснення оперативної та ефективної протидії негативному ІПсВ на військовослужбовців під час виконання службових завдань в умовах загострення суспільно-політичної обстановки через відсутність систем раннього виявлення та оперативної оцінки рівня негативного ППсВ на особовий склад військ (сил) та методики здійснення протидії такому впливу;

велика кількість теоретичних розробок щодо здійснення протидії негативному IПсВ поки ще не доведена до рівня практичних рекомендацій (документів) та застосування у практиці військ.

Одним iз обов'язкових напрямів протидії негативному IПсВ, зокрема, на особовий склад військ (сил) Збройних Сил України, є заходи удосконалення існуючої системи морально-психологічного забезпечення (МПЗ) для мінімізації наслідків такого впливу $[4,5,11]$.

МПЗ підготовки та застосування військ (сил) визначається як сукупність узгоджених за метою, завданнями, напрямами, місцем та часом заходів, які здійснюються командирами (начальниками), штабами, посадовими особами збройних сил 3 метою формування, підтримання і поновлення у особового складу морально-бойових та психологічних якостей, морально-психологічного стану (МПС) особового складу військ (сил) на рівні, необхідному для успішного виконання завдань за призначенням [6, 7].

МПС особового складу військ визначається як сукупність соціальних, службових, морально-етичних, психологічних факторів, що проявляються в конкретних умовах життєдіяльності військових колективів (підрозділів, команд, розрахунків, постів, екіпажів тощо) та окремих військовослужбовців і характеризують готовність (моральні якості, фізичні можливості і психологічні властивості) військовослужбовців виконувати покладені функціональні (службові) обов'язки за посадою, вирішувати поставлені завдання в конкретній бойової обстановці та у визначений час $[1,7,12]$.

МПС $є$ однією 3 основних умов виконання службових завдань, важливим складовим чинником забезпечення високої боєготовності та боєздатності Збройних Сил України, з'єднань, військових частин, підрозділів і окремих військовослужбовців.

Метою статті $є$ обгрунтування способів та заходів удосконалення існуючої системи морально-психологічного забезпечення для захисту (протидіï) особового складу військ (сил) від негативних інформаційнопсихологічних впливів

Виклад основного матеріалу. Події останніх років у світі та в Україні свідчать про те, що одне з важливих місць в системі протидії негативному IПсВ та забезпечення належного МПС належить захисту військ (сил) від негативного IПсВ, який є комплексом дій, що проводяться в мирний та воєнний час державним і військовим керівництвом країни, командуванням, штабами, іншими органами військового управління та посадовими особами військових частин (підрозділів) по запобіганню, нейтралізації (ослабленню), блокуванню та усуненню наслідків негативного ІПсВ на особовий склад військ (сил).

Під негативним ІПсВ розуміють пропагандистські та психологічні дії противника, що спрямовані на [12-14]:

зниження боєготовності та боєздатності військ (сил), зменшення службової активності, дезертирство серед військовослужбовців, симуляцію хвороб, ухилення від виконання наказів командирів та начальників, викривлення картини бойових дій і бойової обстановки;

зниження морального духу, створення обстановки невпевненості i занепокоєння особового складу стосовно свого майбутнього, майбутнього ЗС України та інші військові формування, а у воєнний час - ослаблення волі до військового опору;

нівелювання почуття гордості за свою державу, за свої Збройні Сили та інші військові формування України, нейтралізацію патріотизму військовослужбовців виконувати свій конституційний обов'язок щодо захисту Батьківщини;

розкол військових колективів, суперечності між різними категоріями військовослужбовців;

хибне

сприймання

військовослужбовцями існуючих загроз національній безпеці, дійсних планів і намірів ймовірного противника.

Критеріями очінки МПС особового складу військ (сил) $\epsilon$ :

готовність особового складу до виконання поставлених завдань, рівень навченості та фізичної підготовки;

вірність особового складу військовому обов'язку, військовій присязі, рівень правової свідомості військовослужбовців;

моральні цінності, рівень військової дисципліни і правопорядку; 
пануючі

настрої,

думки

військовослужбовців, стосовно зовнішнього і внутрішнього життя країни та Збройних Сил;

задоволеність військовослужбовців характером військової діяльності та проходженням служби у Збройних Силах; вплив на військовослужбовців соціально-політичних, економічних, криміногенних обставин в районі дислокації; статус військовослужбовців у місцевого населення.

Особливо треба виділити такі сучасні види IПсВ: психогенний, нейролінгвістичний, психокорекційний, психотропний та психотронний $[3,10,14]$. Розуміння цього дозволяє адекватно розробляти адекватні заходи протидії та захисту.

На думку військових дослідників основними напрямками реалізації спеціальних заходів захисту є [2, 7, 15-17]:

роз'яснення військовослужбовцям, цивільному персоналу прийомів та техніки проведення пропаганди, здійснюваних психологічних акцій та дій 3 метою формування установок для їх критичного сприйняття;

роз'яснення військовослужбовцям та цивільному персоналу сутності, цілей, завдань, тематики, форм, методів і технічних засобів ведення психологічних операцій, їх спрямованості, істинних намірів та інтересів;

ознайомлення військовослужбовців 3 фактами, що свідчать про вдосконалені прийоми i методи, які використовуються противником 3 метою впливу на індивідуальну та групову свідомість військовослужбовців; прогнозування тематики й символіки психологічних операцій, можливих IПсВ з метою випередження впливу, зниження його ефективності та нейтралізації;

контроль колективної й громадської думки військовослужбовців і цивільного персоналу у зв'язку з негативним IПсВ; аналіз морально-психологічної обстановки інформаційної, (суспільно-політичної, криміногенної тощо) у районі дислокації військової частини, підрозділу i виконання завдання;

оцінювання ступеня уразливості військових колективів від негативної пропаганди та психологічних впливів (дій) противника;

контроль попередження поширення серед військовослужбовців друкованої продукції деморалізуючого спрямування; фобій; припинення деморалізуючих чуток, профілактика та припинення панічних настроїв військовослужбовців.

Захист військ (сил) ЗС Украӥни від негативного IПсВ має здійснюватися 3 метою (рис. 1):

зниження небезпеки негативного IПсВ на командування, посадових осіб органів управління та особовий склад;

забезпечення ефективного управління військами (силами) і створення сприятливих умов для їх оперативного застосування;

зміцнення МПС військ (сил);

своєчасного запобігання розвитку у військових колективах небажаної ідеології та іiі впливу на командування i особовий склад частини (підрозділу).

Захист військ (сил) від ІПсВ противника - це цілеспрямований комплекс заходів, що проводяться в мирний та військовий час командуванням, штабами, органами виховної роботи та іншими посадовими особами щодо попередження, виявлення, нейтралізації (послабленню), блокуванню та ліквідації наслідків негативного ІПсВ на військовослужбовців і населення

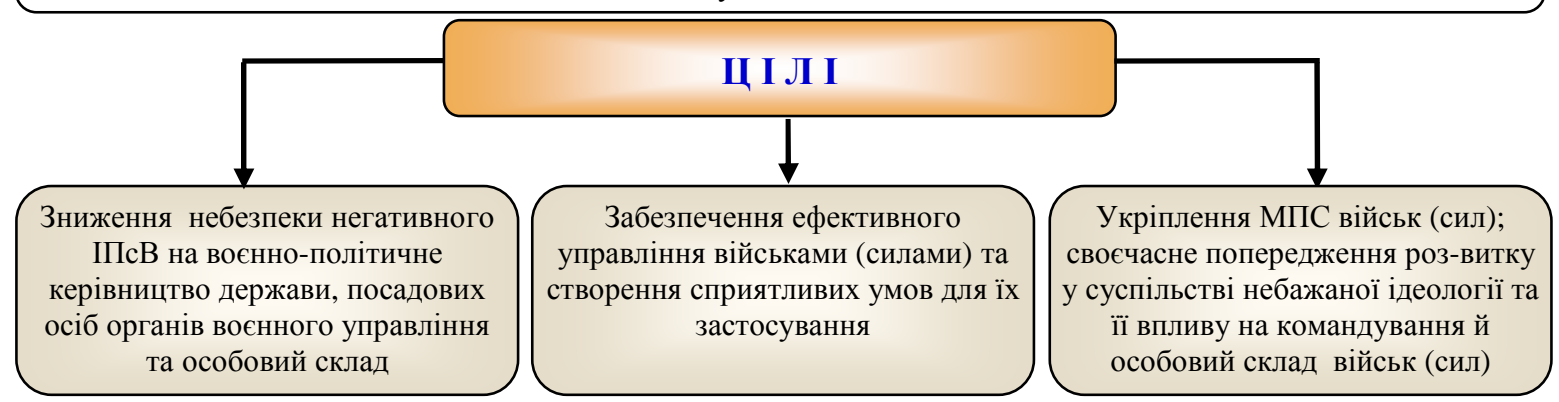

Рис. 1. Цілі захисту військ від ІПсВ

Виходячи 3 цього, до основних завдань захисту військ (сил) від негативного $I \Pi$ с можна віднести $[14,16]$ :

роз'яснення рішень військовополітичного керівництва країни, завдань, що стоять перед військами (силами), перед кожним військовослужбовцем;

здійснення постійного моніторингу інформаційного простору 3 метою виявлення реальних та потенційних інформаційних загроз 
та проведення інформаційних заходів;

аналіз i прогнозування воєннополітичної, соціально-політичної та інформаційної обстановки; збір та узагальнення даних про джерела i зміст (контент) негативного ІПсВ на особовий склад військ (сил) 3 розробкою конкретних заходів по його усуненню (ліквідації наслідків);

оперативну нейтралізацію негативного IПсВ та його джерел 3 метою недопущення деморалізації, дезінформації, моральнопсихологічного придушення військ (сил);

зміну на свою користь співвідношення у морально-психологічній стійкості протиборчих сторін, підтримку iii на рівні, необхідному для вирішення поставлених завдань в ході підготовки і ведення бойових дій; проведення превентивних інформаційнопсихологічних акцій, направлених на свої війська (сили) та місцеве населення;

організацію та завчасне проведення профілактичних заходів по запобіганню поширення хибних чуток серед особового складу, недопущенню виникнення масових негативних психічних реакцій; припинення чуток, тривожних висловів і протиправних дій, направлених на зниження МПС військ.

За своєю структурою захист військ (сил) від ІПсВ противника передбачає такі кроки: прогнозування; запобігання (попередження та профілактика); зрив (нейтралізачія) та ліквідація наслідків реалізації негативного інформаційно-психологічного впливу (рис. 2, рис. 3).

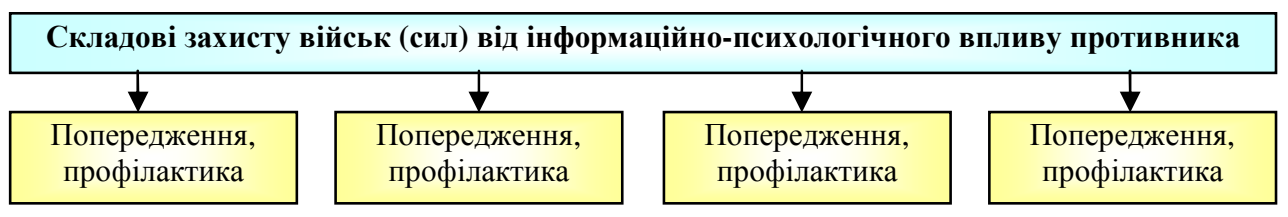

Рис. 2. Структура (складові) захисту військ від негативного ІПсВ

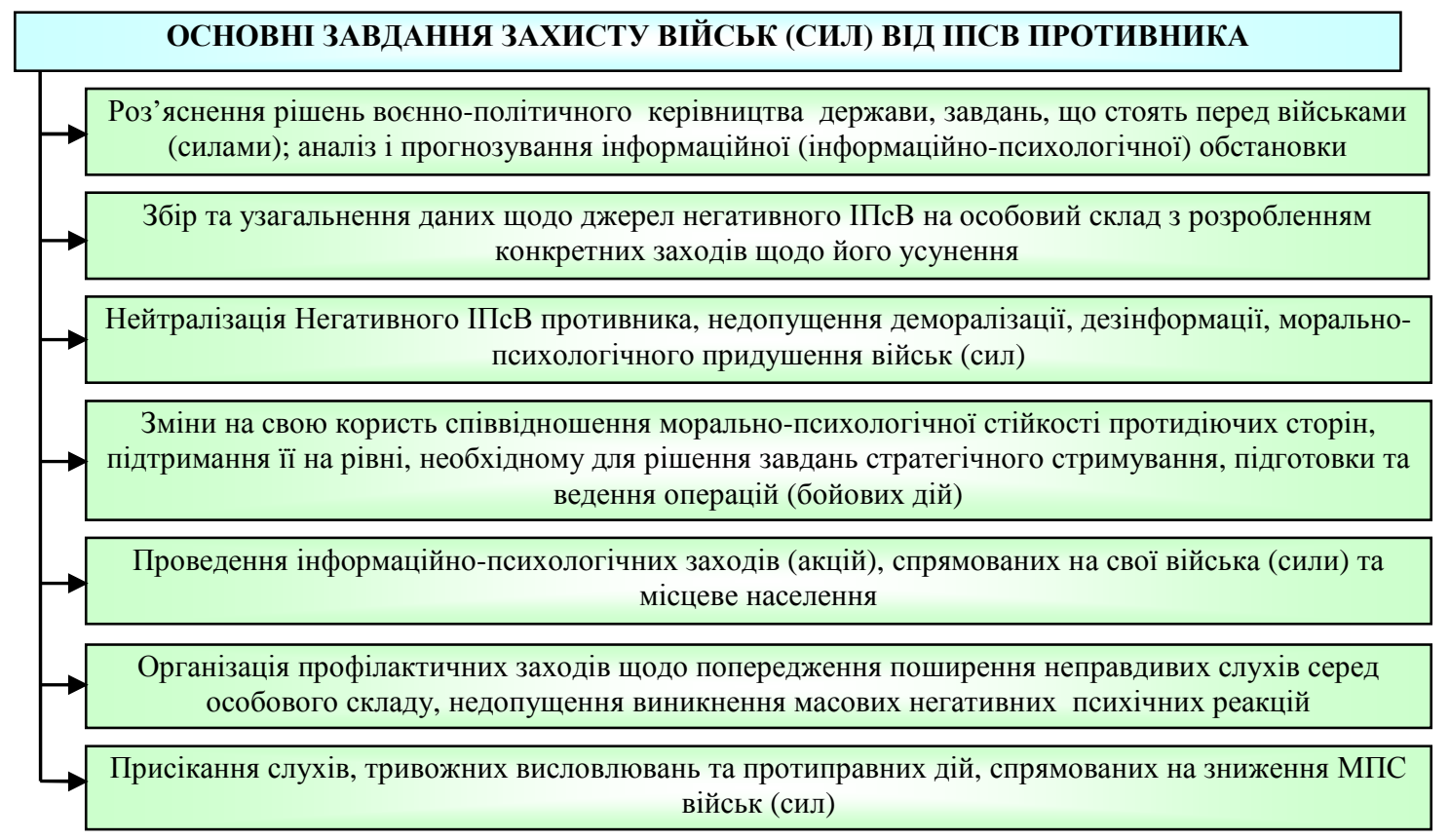

Рис. 3. Основні завдання захисту військ від ІПсО

Прогнозування націлене на вирішення ряду таких завдань:

оволодіння знаннями про власні сили інформаційно-психологічної протидії, що можуть бути задіяні для проведення необхідних заходів;

оцінити інформаційну і моральнопсихологічну обстановку в районах дислокації та ведення бойових дій військ (сил);

виявити сили, засоби, рубежі та райони зосередження основних зусиль інформаційних (психологічних) операцій противника, їх можливості, спрямованість підривної пропаганди, об'єкти i можливі канали потенційного впливу;

передбачити можливий рівень психогенних втрат особового складу від пропагандистського та психологічного впливу противника.

Прогнозування полягає також в передбаченні основної тематики і символіки ІПсВ. Основою такого прогнозу є глибоке знання реального положення справ у підрозділах i поточного рівня МПС особового складу. Можна 
також заздалегідь передбачити, що противник не упустить можливості ідеологічного та психологічного впливу з врахуванням недоліків у їх матеріально-технічному забезпеченні, наявності недосвідчених керівників, несприятливих подій та процесів у країні, низького рівня підготовки особового складу, прорахунків у інформуванні особового складу, фактів порушення дисципліни та законності, національних та інших протиріч.

Профілактика наслідків негативного $\mathrm{I \Pi cO}$ передбачає здійснення низки заходів, направлених на зниження сприйнятливості та схильності особового складу до цього впливу: чітке роз'яснення особовому складу дійсних цілей, способів, можливих наслідків і психологічних механізмів деформації свідомості військовослужбовця під впливом ворожої пропаганди. Практика показує, що якщо в екстремальній обстановці раптово настає подія, по відношенню до якої у людини немає досвіду, реагування та його поведінка стають непередбачуваними. обов' язкове

попередження

військовослужбовців про принципи підривної пропаганди. Досвід показує, що противник прагне першим повідомляти про певні події, щоб досягти психологічного ефекту “первинності”, тобто міцнішого закріплення першої інформації про те, що сталося. Традиційно фахівці IПсВ в інформаційному повідомленні перемішують правдиву інформацію 3 дезінформацією, підвищують авторитет своїх акцій за рахунок оперування знайомими прізвищами, назвами міст, вулиць, датами, фактами, шляхом залучення думок відомих осіб (політиків, спортсменів, діячів мистецтва і культури). Ефективним прийомом $€$ приписування відповідальності за невдачі, прорахунки, безлади конкретним людям (командирам, органам влади, державним діячам, політикам, депутатам та ін.) в цілях їx дискредитації;

ретельний підбір осіб для роботи на засобах зв'язку та управління. Серед них не повинно бути людей психічно неврівноважених, невитриманих, з демонстративною акцентуацією характеру, боязких. Ці люди мають усвідомлювати, що їх реакції, настрої та вислови можуть інтерпретуватися як прямий наслідок володіння ними певною інформацією.

Протидіюча сторона може спеціально або неусвідомлено "підігравати” окремі засоби масової інформації (3МI). Тому відповідним керівникам при спілкуванні 3 представниками 3MI необхідно враховувати це та організовувати контрольований порядок надання їм інформації, контактів із військовослужбовцями, поширення серед особового складу друкарських видань тощо.
Для забезпечення морально-психологічної стійкості військовослужбовців до негативного ІПсВ необхідне засвоєння ними певних знань, умінь і навичок, до яких відносяться $[12,14,16]$ :

знання методів i прийомів протидії негативному ІПсВ та їх адекватного вибору;

уміння виявляти, розпізнавати ознаки негативного IПсВ;

навички мобілізації ресурсів особи для протидії негативному IПсВ;

навички здійснення безпосередньої протидії ІПсВ (вибору і використання психотехніки протидії в міжособовій та масовій комунікації);

навички самопізнання рефлексії i

саморегуляції;

навички колективної протидії чуткам та домислам, що дестабілізують і деморалізують МПС особового складу.

Запобігання IПсВ противника передбачає:

своєчасне визначення початку IПсВ, направленого на підрив морально-психологічній стійкості особового складу;

безперервне, об'єктивне, психологічно доцільне бойове i політичне інформування особового складу та роз'яснення йому дійсних цілей, завдань, тематики, методів, технічних засобів та можливих наслідків ІПсВ противника;

надійне перекриття каналів IПсB противника на військовослужбовців та місцеве населення;

визначення та організацію роботи підрозділів (військовослужбовців) відповідних структур по збору та знищенню матеріалів негативного ІПсВ противника;

виявлення психічно та психологічно нестійких військовослужбовців i проведення 3 ними індивідуальної психопрофілактичної роботи;

організацію в підрозділах (частинах) системи товариської взаємної підтримки і психологічної допомоги на основі впровадження методів інтервізії;

ознайомлення військовослужбовців 3 витонченими прийомами i методами IПсВ противника, що використовуються 3 метою психологічного придушення індивідуальної та групової свідомості військ (сил);

розвідку, придушення і знищення сил та засобів інформаційно-психологічних (психологічних) операцій противника;

оцінку ступеня уразливості своїх військ (сил) від ІПсВ противника, прогнозування наслідків та планування заходів щодо оперативної протидії;

організацію профілактичних заходів по запобіганню негативних наслідків IПсB на військовослужбовців (зниження психологічної стійкості, рівня бойової готовності, спроби здачі в полон та ін.); 
нарощування засобів IПсВ на свої війська (сили) і місцеве населення та світову спільноту тощо.

Зрив (нейтралізаичія) IПсВ на особовий склад військ (сил) досягається:

своєчасною розвідкою та знищенням (нейтралізацією) сил i засобів інформаційнопсихологічних операцій (IПсО) противника; оперативним збором, аналізом i знищенням пропагандистських матеріалів противника;

рішучим припиненням паніки, чуток, ізоляцією військовослужбовців (підрозділів), що піддалися деморалізації;

постійним відстежуванням і підвищенням

МПС особового складу;

\section{безперервним}

інформуванням

військовослужбовців про зміни обстановки, про застосування противником нової зброї та засобів $\mathrm{I \Pi cB}$;

здійсненням інформаційної взаємодії (органів психологічної боротьби, розвідки, радіоелектронної боротьби, зв' язку, МПЗ та ін.).

Зрив ІПсВ передбачає швидке виявлення засобів впливу, їх негайне придушення або нейтралізація. Виявлені підривні акції підлягають негайному i кваліфікованому аналізу, виявленню їх цілей, можливої динаміки, міри дієвості. Кожна 3 цих акцій не повинна залишатися без відповідної контрпропагандистської відповіді.

Ліквідація наслідків ІПсВ передбачає:

виявлення військовослужбовців (підрозділів), що піддалися деморалізації, діагностику їхнього МПС та надання необхідної допомоги;

аналіз і оцінку результатів IПсВ, причин ефективності, найбільш слабких місць в системі інформаційно-психологічного захисту особового складу;

виявлення причин виникнення явищ дезорганізації серед особового складу та їх усунення;

відновлення організованості і боєздатності дезорганізованих підрозділів, надання психологічної допомоги тим, хто її потребує;

вживання відповідних заходів щодо оптимізації всієї системи протидії ІПсВ противника;

застосування відповідних санкцій (притягнення до відповідальності) до розповсюджувачів деморалізуючих чуток i панікерів, визначення заходів по оптимізації всієї системи протидії ІПсВ противника.

Основними формами захисту військ (сил) від ІПсВ $\epsilon$ [15-17]:

окремі інформаційно-пропагандистські, інформаційно-психологічні та оперативнопрофілактичні акції; комплекс заходів інформаційнопропагандистського та оперативнопрофілактичного характеру;

спеціальні інформаційні операції щодо протидії негативному IПсВ.

При цьому найбільшу ефективність показує така форма захисту, як інформачійнопропагандистські акиіï, що проводяться з метою: зниження небезпеки дезінформуючого i психологічного впливу на командування та особовий склад; забезпечення ефективного управління військами (силами) та створення сприятливих умов для їх застосування;

своєчасного запобігання розвитку $\mathrm{y}$ військових колективах небажаної ідеології та іiі впливу на командування i особовий склад частини (підрозділу);

підтримка авторитету застосування військ (сил); формування громадської думки на їх підтримку та формування повної злагоди i взаєморозуміння між органами місцевого самоврядування, місцевим населенням і силовими структурами, що беруть участь в бойових діях;

забезпечення захисту інформаційної сфери, у тому числі виявлення потенційних загроз та уразливих місць у власній системі зв'язку; підтримка високого рівня інформаційної безпеки (у воєнній сфері тощо) та готовності до виконання завдань за призначенням; нейтралізації негативних IПсВ у ЗМІ тощо. Ефективність захисту військ (сил) від IПсВ досягається: врахуванням особливостей IПсB противника та реального МПС військ (сил) i обстановки, що складається; оперативністю, безперервністю та комплексністю заходів протидії ІПсВ противника, високим рівнем інформаційно-аналітичної роботи та рішеннями, що прийняті за їі рекомендаціями; врахуванням психологічних закономірностей сприйнятяя людиною інформації, особливо в зоні (районі) напруженості та нештатних (надзвичайних, військових та ін.) ситуацій;

оснащеністю військ (сил) сучасними технічними засобами протидії IПсВ та навчання сучасним методам забезпечення інформаційної безпеки особового складу, протидії проявам інформаційного тероризму (інформаційній зброї).

Основою створення системи протидії та захисту військ (сил) від негативного ІПсВ мають бути духовно-етичні цінності українського суспільства. Такі поняття як Патріотизм, Вітчизна, Обов'язок, Честь не повинні ставитися під сумнів на користь політичній кон'юнктурі.

Важливою складовою системи протидії та захисту військ (сил) від ІПсВ $\epsilon$ історична самосвідомість військовослужбовців. Значно простіше маніпулювати свідомістю тих людей, які не знають історії свого народу, свого 
історичного коріння. Тому не лише особисте майбутнє має турбувати кожного військовослужбовця, але й майбутнє його країни.

Обов'язковою ланкою протидії та захисту військ (сил) від ІПсВ має бути нейтралізація акцій, направлених на пониження престижу та авторитету військової служби у ЗС України.

Ідея державного патріотизму, висока історична самосвідомість, гордість за свою військову професію та належність до збройних сил $є$ передумовами формування стійкості до психологічних операцій i вони мають стати основою всієї системи протидії ІПсВ.

Якщо у військовослужбовців виникають ситуації, що пов'язані 3 екстремальними ситуаціями чи хвилюваннями взагалі, доцільно застосовувати магічну формулу Уілліса X. Keppiepa:

Запитати себе: “Що є найгіршим із того, що може відбутися?”.

Приготуйтеся змиритися 3 цим у випадку необхідності. ситуацію.

Потім спокійно подумати, як змінити

Загальноприйняте: моральність та співчуття, вміння бачити красу завжди вважалися надійним способом збільшення психологічної стійкості, вміння та спроможності спасти себе і надати допомогу товаришам.

Подальші дослідження слід присвятити аналізу та визначення змісту конкретних заходів забезпечення інформаційно-психологічної безпеки особового складу військ (сил), зокрема використання системи стратегічних комунікацій як засобу протидії негативним інформаційнопсихологічним впливам; розвиток у військовослужбовців стратагемного та критичного мислення щодо ефективної протидії інформаційно-психологічному впливам; визначення критеріїв і індикаторів (показників) стану інформаційно-психологічної безпеки особового складу військ (сил).

\section{Висновки.}

1. Організований IПсВ на людей $\epsilon$ специфічним явищем сучасності, важливим та ефективним засобом досягнення різних цілей на тактичному, оперативному i стратегічному рівнях в умовах ведення інформаційної війни як основи гібридної війни. Негативний $\mathrm{I \Pi cB}$ на військовослужбовців все частіше використовується різними дестабілізуючими силами як інформаційна зброя, що знижує готовність і здатність особового складу якісно та ефективно виконувати покладені на них службові та бойові завдання. Тому ефективна діяльність особового складу, органів військового управління в сучасних умовах неможлива без забезпечення готовності військовослужбовців до інформаційно-психологічної протидії.
2. Психологічними умовами ефективної протидії негативному ІПсВ на особовий склад $є$ формування у них позитивної мотивації до служби в ЗС України, особистому і професійному військовому вдосконаленню та розвиток навиків виявлення, вибору і реалізації техніки та стратегій індивідуальної і групової протидії негативному IПсВ, створення у військовому колективі обстановки відвертості та щирості при обговоренні актуальних проблем життєдіяльності підрозділу, соціально-політичної та інформаційної обстановок; розвиток колективних навиків протидії чуткам i домислам, що дестабілізують та деморалізують особовий склад.

Реалізація цих умов дозволить підвищити ефективність системи протидії негативному інформаційно-психологічному впливу на особовий та керівний склад 3С України, інших військових формувань як в екстремальних, так i звичайних умовах військової діяльності.

3. Отже, під час проведення бойових дій необхідно враховувати, що:

сучасне інформаційне та інше оперативне забезпечення включає в себе низку заходів, які потрібно виконувати в повному обсязі для досягнення (забезпечення) максимальної безпеки військовослужбовців;

мінімізація наслідків від заходів інформаційних операцій противника залежить від правильних рішень командирів та інших ланок військового управління, злагоджених дій військових колективів, підрозділів, частин, угруповань військ (сил), підрозділів інших військових формувань та цивільного населення; навички протидії та захисту від негативного ІПсВ противника мають бути заздалегідь добре засвоєні кожним військовослужбовцем.

\section{СПИСОК ВИКОРИСТАНОЇ ЛІТЕРАТУРИ}

1. Петрик В.М. Сучасні технології та засоби маніпулювання свідомістю, ведення інформаційних війн i спеціальних інформаційних операцій: Навчальний посібник / Петрик В.М., Остроухов В.В., Штоквиш О.А. та ін. / За ред. В.М. Петрика. - К.: Росава, 2006. - 208 с.

2. Литвиненко О.В. Спеціальні інформаційні операції та пропагандистські кампанії. - К.: ВКФ “Сатсанга”, 2000.

3. Почепцов Г.Г. Психологические войны. - М.: Рефл-бук, К.: Ваклер, 2000. - 576 с.

4. Крысько В.Г. Секреты психологической войны (цели, задачи, методы, формы, опыт) / Крысько В.Г. - Мн.: Харвест, 1999.

5. Андриевский. И.А. Некоторые аспекты современных форм и способов враждебного противостояния и вооруженного притивоборства / Андриевский. И.А. // Наука и Безопасность: [Електронний ресурс]. - Режим доступу : http://www.art-atis.com/Docs/03_mar_2012.pdf.

6. Інформаційна безпека держави у контексті протидії інформаційним війнам. Навчальний посібник / За ред. В.Б. Толубка / - К.: НАОУ. - 2004. -179 с.

7. Богуш В.М. Основи інформаційної безпеки держави: Вступ до спеціальності / В. Богуш, О. Юдін. - Харків: Консум, 2004. - 439 с. 
8. Бондаренко В.О. Інформаційні впливи та інформаційні операції / В. Бондаренко, О. Литвиненко. - К.: Стратегічна панорама, - № 4. - 1999. - С. 134-139.

9. Кормич Б.А. Інформаційна безпека: організаційноправові основи. Навчальний посібник. - К.: Кондор, 2008. - 384 c.

10. Егоров А. Это должен знать каждый. Негативное информационно-психологическое воздействие / А. Егоров. // Журнал прикладной психологии. - 2002. - № 3. - C. 52-55.

11. Алещенко В.I. Проблеми захисту від негативного інформаційно-психологічного впливу противника /
Алещенко В.І., Сербін В.Г. - Математичні машини і системи, 2010. - № 1.

12. Конах В.К., Рогов П.Д. Зовнішні негативні інформаційно-психологічні впливи на Україну та можливі шляхи їх нейтралізації. / Сучасна українська політика. - К.: Вид-во “Центр соціальних комунікацій”, 2013. - Вип. 29. - С. $134-150$.

13. Рогов П.Д., Присяжнюк М.М. Війна за мізки. Оборонний вісник, 2016, № 6. - С. 20 - - 25.

14. Онищук М.I. Протидія інформаційно-психологічному впливу противника: Навчально-методичний посібник / Онищук M.I. - К.: НАОУ, 2002. - 36 с.

Стаття надійшла до редакції 23.06.2017

Рогов П. Д., к.т.н. ${ }^{1}$;

Ткаченко В. А., к.воен.н. ${ }^{\text {; }}$

Голубцов С. Н. ${ }^{2}$

1 - Центр военно-стратегических исследований Национального университета обороны Украины имени Ивана Черняховского, Киев;

${ }^{2}$ - Институт государственного военного управления Национального университета обороны Украины имени Ивана Черняховского, Киев

Усовершенствование морально-психологического обеспечения как неотъемлемая составляющая защиты войск (сил) и противодействия негативному информационно-психологическому влиянию

Резюме. В статье рассмотрено информационно-психологическое воздействие, как специфическое явление современности и эффективный способ достижения целей на тактическом, оперативном и стратегическом уровнях. Рассмотрена система противодействия негативному информационному воздействию на личный и руководящий состав ВС Украины в экстремальных и обычных условиях деятельности.

Ключевые слова: защита, информационно-психологическое противодействие, информационнопсихологическое воздействие.

\section{P. Rogov, Ph.D ${ }^{1}$;}

V. Tkachenko, Ph.D ${ }^{1}$;

S. Golubtchov ${ }^{2}$

${ }^{1}$ - Center for Military and Strategic Studies of the National Defence University of Ukraine named after Ivan Chernyhovsky, Kyiv;

${ }^{2}$ - Institute of State Military Management of the National Defence University of Ukraine named after Ivan Chernyhovsky, Kyiv

Improvement of the morally-psychological providing as inalienable constituent of defence of troops (forces) and counteraction to negative informatively-psychological influence

Resume. An information and psychological impact as a specific modern phenomenon and effective means of achieving the objectives at the tactical, operational and strategic levels is analyzed. A system to counteract the negative information impact on personnel and commanding staff of the Armed Forces of Ukraine in the extreme and ordinary operating conditions is examined.

Keywords: defence, informatively-psychological counteraction, informatively-psychological influence. 